\title{
Korespondencja Adama Mickiewicza ze Stefanem Garczyńskim
}

Grzegorz Szelwach 
KAPIS Seria V 1999

\section{Grzegorz Szelwach}

\section{Korespondencja Adama Mickiewicza ze Stefanem Garczyńskim}

1. $W_{\text {jak „przyjaciel w pełnym znaczeniu tego słowa, bo i towarzysz wędrówek i tułaczki }}^{\text {ydaje sièe żaden z przyaciół nie był Mickiewiczowi tak sympatycznym i drogim }}$ i słuchacz pilny i uczestnik «teologicznych sporów» i pisarz-kolega - Stefan Garczyński, "Stefunio»"1. Nic też dziwnego, że do czasu przyjazdu Garczyńskiego do Rzymu, czyli do 3 marca 1830 roku, Mickiewicz czul się osamotniony w towarzystwie różniącego się mentalnością Antoniego Edwarda Odyńca, na co skarżył się Franciszkowi Malewskiemu: „(...) mój towarzysz zbyt różni się i wiekiem i myślami, i całym życiem; nie ma więc między nami takich związków, w jakich żyć przywykłem" (Rzym, 2 II 1830; XIV 514)². Jeszcze dobitniej pisał później o swym rozminięciu się z Odyńcem w liście do Józefa Jeżowskiego: „Jestem moralnie samotny zupełnie, bo towarzysz mój dobry już całym niebem różni się ode mnie i sposobem myślenia, i czucia, i nie mając między sobą języka, zamknęliśmy się w skorupach; wyjąwszy to, że razem mieszkamy, zdaje się, żeśmy daleko od siebie" (Rzym, koniec II 1830; XIV 520). Zatem przybycie Stefana zmieniło bardzo sytuację poety, ponieważ Garczyński przewyższał „trzpiotowatego” Odyńca swym refleksyjnym umysłem, powagą i szerszym horyzontem zainteresowań. Jego wzajemne stosunki z Mickiewiczem mogły ułożyć się

\footnotetext{
' M. Danilewiczowa, Miles, vates, exul [w:] taż, Pierścień z Herkulanum i plaszcz pokutnicy. Szkice literackie, Londyn 1960, s. 63.

${ }^{2}$ Wszystkie cytaty z listów Adama Mickiewicza pochodzą z Wydania Jubileuszowego Dziet pod red. J. Krzyżanowskiego, Warszawa 1955, t. XIV-XV (dalej oznaczane w tekście nazwą miejscowości, datą, liczbą tomu i numerem strony).
} 
inaczej niż Odyńca, który wprawdzie pisał, że podczas pierwszej wizyty gospodarz nie poznał Garczyńskiego i dopiero on sam uratował sytuację, ale ten nieoczekiwany przebieg spotkania wynikał raczej, jak wolno sądzić, ze skrępowania obecnością Odyńca ${ }^{3}$.

Przyjaźń Mickiewicza z Garczyńskim utrzymana była w romantycznym stylu, jak niegdyś, gdy w okresie kowieńsko-wileńskim poeta miał silne i prawdziwe związki uczuciowe ze swoimi kolegami-filomatami. Mickiewicz bardzo potrzebował takiej przyjaźni prawie przez całe swoje życie.

Obecnie znanych jest osiem listów Mickiewicza do Garczyńskiego i jedenaście Garczyńskiego do Mickiewicza. Obejmują one między innymi okres powstania listopadowego (wysłane z Łukowa w Wielkopolsce), jeden wcześniejszy wysłany przez Mickiewicza z Rzymu, większość zaś jest wymianą korespondencji między Paryżem a Dreznem (z wyjątkiem dwóch ostatnich listów Garczyńskiego wysłanych z Frankfurtu i ze Strasburga). Wicle z tych listów zaginęło, tzn. wszystkie Garczyńskiego do Mickiewicza z 1831 roku oraz Mickiewicza do Garczyńskiego z 1832 i czerwca 1833 roku. Wiadomo zresztą, że listy Mickiewicza dotarły do nas po cenzurze Władysława Mickiewicza — syna poety, który usuwał z korespondencji ojca niektóre fragmenty. Przez to znamy ją na tyle, na ile nam pozwolił.

W czasie, kiedy się poznali, Mickiewicz był znanym poetą o dużym dorobku, Garczyński znaczył jeszcze wtedy niewiele i nie ujawniał nikomu swej twórczości. W Rzymie obydwaj rozmawiali na tematy z zakresu filozofii, literatury i polityki, zapewne nieraz też ścierały się ich różne stanowiska wobec filozofii $\mathrm{Hegla}^{4}$, a może także na temat szans powodzenia powstania zbrojnego w Polsce. W kilka miesięcy później było dane im przekonać się o tym osobiście.

\footnotetext{
${ }^{3}$,W przeszłą sobotę, dnia 3 (...) marca, siedzieliśmy sobie, jak zwykle po kawie, zatopieni każdy w swojej literaturze. A wtem otwierają się drzwi i wchodzi jakiś młodzieńczyk, blondyn ładny, rumiany i z wesołym uśmiechem, jakby pewny serdecznego przyjęcia, idzie wprost ku Adamowi. Ten podniósł oczy, spojrzał, ale ani się ruszył z kanapy. Młodzieńczyk zachwial się nieco, ale nie tracąc fantazji zbliża się i zapytuje: «Pan mnic nie poznaje?" - «Przepraszam» - odpowiada mu zimno, nie rozbudzony jeszcze z zaczytania Adam. «Jestem Stefan Garczyński». Adam się przecież poruszył, ale widać było wyraźnie, że nie lepiej nazwisko gościa jak i rysy jego przypominał. Młodzieńczyk zmieszał się strasznie, pobladł raptem i poczerwieniał, że aż mi się żal go zrobiło, tym bardziej, że mi przyszła na pamięć własna moja niegdyś scena z Chodanim. Dopiero gdy mu wydeklamował wyraźnie i dobitnie, że się poznali w Berlinie i że on go to pierwszy zaprowadził i zapoznał z Gansem [historykiem - G. S.], dopiero wreście Adam przyszedł do roztropu i zaczął spełniać obowiązek gościnnego i uprzejmego gospodarza. Ja zaś, aby zatrzeć do reszty to niemiłe wrażenie, odezwałem się żartobliwie do gościa, że jeśli liczył na pamięć pana Mickiewicza co do fizjognomii i nazwisk, to się fatalnie omylił, bo ja myślę, że on sam siebie kiedyś we zwierciadle nie pozna, jak już raz swego nazwiska zapomniał. (...) Adam zaczął się śmiać, a młodzieńczyk nie pytając nawet kto jestem, zwrócił się do mnie z tak miłym uśmiechem i tak czule podał mi rękę, że mi się (...) od razu podobał" (A. E. Odyniec, Listy z podróży, opr. M. Toporowski, wst. M. Dernałowicz, t. 2, Warszawa 1961, s. 198-199 - do Ignacego Chodźki, Rzym, 9 III 1830).

"Hegel „serce i umysł (...) Stefana jak pająk pszczołę oplątał" - pisał Odyniec w tym samym liście do Chodźki (op. cit., s. 205), a Julianowi Korsakowi opisywał Garczyńskiego: „w teoriach, w myślach, a zwłaszcza w rozumowaniach kręci się, jak derwisz w meczecie, w formułkach myśli niemieckiej, a już jak przed trumną Proroka bije czołem przed systemem Hegla" (Rzym, 14 III 1830; tamże, s. 219). Wladysław Mickiewicz w Żnuocie Adama Mickiewicza (t. 2, Poznań 1892, s. 99), zaznacza iż „Garczyński (...) całą energią trawil na zgłębianie systematów filozoficznych niemieckich, gdy Adam oderwał go od spekulacji abstrakcyjnych i otworzył mu dziedzinę poezji”. Jednocześnie sam poeta przyznawał w liście do Hieronima Kajsiewicza: „Ja
} 
2.

Wiadomość o wybuchu powstania listopadowego dotarła do Garczyńskiego w Rzymie w połowie grudnia 1830 . Nie zważając na zły stan zdrowia, postanowił natychmiast wyruszyć z Rzymu ${ }^{5}$, aby wziąć czynny udział w walce o wolność Polski, „gna do kraju, gruźlicę na kołku wiesza" ". Wyjeżdża przez Niemcy i rodzinną Wielkopolskę do Królestwa, w Warszawie jest już w początkach lutego 1831 roku. Wstępuje do armii jako zwykły szeregowiec.

To, że Mickiewicz ostatecznie nie wziął udziału w powstaniu, jest osobną sprawą, o której już wypowiedzieli się mickiewiczologowie ${ }^{7}$. Faktem pozostaje, że wyjazd Garczyńskiego skłonił Mickiewicza do powzięcia odpowiedniej decyzji. Pozostał jednak we Włoszech, zwlekał z wyjazdem. W marcu 1831 roku pisał do Garczyńskiego: „Siedzę dotąd w Rzymie i dręczę się i nudzę. Różne okoliczności wyjazd mój wstrzymały. Teraz w Romanii rozruchy i drogi nie bardzo bezpieczne. Myślę jednak ruszyć, zwlaszcza że mam o czym. Twoje 300 thal. odebrałem. Wypłacę Rzewuskiemu za Hubego 200 franków, sobie 100. Resztę, czy nie odbierzesz u Waleriana [Krasińskiego], bo i sam potrzebuję kilkuset franków?” (Rzym, 2 III 1831; XIV 578). Jarosław Maciejewski zauważa, że list ten należy czytać w kontekście jakiejś akcji zbierania pieniędzy na rzecz powstania. „(...) A więc Mickiewicz odebrał w Rzymie 300 talarów, czyli 1080 franków, które powinien był odebrać od kogoś Garczyński. Po załatwieniu jego i Romualda Hubego długów, które obaj zaciaggnęli u Henryka Rzewuskiego (prawdopodobnie na koszta podróży do Warszawy), resztę, tj. jeszcze 680 franków — poleca Mickiewicz odebrać Garczyńskiemu w Warszawie z swoich własnych, zebranych tam za sprzedaż książek pieniędzy, którymi dysponował Walerian Krasiński”

Tymczasem wcześniej - 19 lutego - wsławił się Stefan Garczyński w bitwie pod Grochowem, za co awansował do stopnia wachmistrza drugiego szwadronu Jazdy Poznańskiej, 18 marca był już podporucznikiem i adiutantem generała Jana Nepomucena Umińskiego. 30 sierpnia już jako porucznik brał udział w dwudniowej walce o stolicę, 12 września został odznaczony Zlotym Krzyżem Wojskowym, a w dniu dramatycznej kapitulacji - 25 września został zdemobilizowany rozkazem szefa Sztabu Głównego — Ludwika Kamińskiego 9 .

przynajmniej nie mógłbym go [Hegla - G. S.] zrozumieć bez objaśnień i wykładów Garczyńskiego, który wiele lat Hegla słuchał" (Paryż, koniec XI 1833; XV 109).

${ }^{5}$ Według świadectwa Sergiusza Sobolewskiego, tuż przed wyjazdem z Rzymu Garczyński zakradł się do mieszkania Mickiewicza i zabrał mu gotówkę, potrzebną na opłacenie podróży do powstańczej Warszawy, aby je zwrócić dopiero w lutym 1831 roku. Opóźniło to znacznie podróż Mickiewicza, który z powodu braku środków finansowych wyjechał z Rzymu do Paryża dopiero 19 kwietnia, udając się w dalszą drogę w kierunku ziem polskich (zob. R. M. Blüth, Psychogeneza „Snuw Dreźnie”, „Przegląd Współczesny” 1925 nr 39, s. 97-111, przedr. [w:] tenże, Pisma literackie, Kraków 1987, s. 30). Bogdan Zakrzewski nazywa opowieść Sobolewskiego „bałamutna”" (Mickiewricz w Wielkopolsce, Poznań 1949, s. 44).

"J. Sztaudynger, O poecie, któremu Mickiewicz urystawit pomnik w Avinionie, „Czas” 1938 nr 277, s. 9.

7 Podniosłem tę kwestię w Korespondencji Adama Mickiewicza z Joachimem Lelewelem, „Napis”, seria III, 1997, s. 127. Por. Z. Stefanowska, Geniusz poety, geniusz narodu. Mickiewicz wobec poustania listopadowego, „Teksty Drugie" $1995 \mathrm{nr}$ 6, s. 19-31.

${ }^{8} \mathrm{~J}$. Maciejewski, Mickieu'icza wielkopolskie drogi. Rekonstrukcje i refleksje, Poznań 1972, s. 86.

9 Informacje za: Z. Szelagg, Stefan Garczyniski w poustaniu listopadowym, „Fakty” 1980 nr 47, s. 9. 
Wyczerpany fizycznie i psychicznie powrócił do Lubostronia w Poznańskiem. Stamtąd 25 października 1831 roku pisze do Odyńca: „Stan mój umysłowy jest okropny. Boże, Boże! kiedyż się zakończy?... [Wspomina jeden epizod z powstania] Mój koń padł zabity. Kula trafiła w pałasz i zgięła zupełnie. Ja żyw zostałem. Przecież gdybym był wiedział... byłbym śmierć przymusił..."10.

Garczyński był pod stałym nadzorem pruskiej policji, wiedział też, że za udział w powstaniu zostanie skonfiskowany jego majątek, a nade wszystko glęboko przeżywał upadek powstania, za który obwiniał jego nieudolnych przywódców. Ten list do Odyńca jest odbiciem wszystkich jego zwątpień, wszystkich rozczarowań i niepowodzeń po złożeniu broni i kapitulacji Warszawy.

Gdy Mickiewicz znalazł się w Poznańskiem, „ciceronować mu będzie Garczyński in persona lub per procuram a Litwin rzemiennym dyszlem krążyć będzie po spowinowaconych ze Stefuniem dworach (...)"11. Kiedy na moment ich drogi się rozeszły, zniecierpliwiony Mickiewicz pisze 27 grudnia do Garczyńskiego, nie znając powodów, dla których nie powrócił do Łukowa, majątku Józefa Grabowskiego: „Czekałem na ciebie wierząc twoim obietnicom. Widać, że (...) całe pokolenie kasztelańskie Wielmożnych Garczyńskich niesłowne" (Eukowo, 27 XII 1831; XIV 598).

Tak więc rozdzieleni przyjaciele w tym okresie utrzymywali korespondencję. Dziś z tamtego okresu znane są tylko dwa listy Mickiewicza do Garczyńskiego, listy tego ostatniego zaginęły, a było ich więcej, skoro Mickiewicz pod sam koniec roku pisze: „Gdybyś mnie w każdym liście po trochu siebie przesyłał, już by cię z połowa przybyła do nas. Zawsze i to dobrze, że mam co dzień od ciebie listowne dobranoc albo dzień dobry. (...) Słychać, że masz z p[anią] Plater jechać, która podobno za kilka dni wyruszy; jakże więc będziemy mogli widzieć [się] z sobą?" (Eukowo, ok. 29-31 XII 1831; XIV 599).

Stefan Garczyński nie przebywał w Wielkopolsce długo. Śledzony przez policję i zagrożony więzieniem zmuszony był do wyjazdu. Udał się do Drezna w początkach stycznia 1832 roku, rozpoczynając życie wygnańca.

Wiosną 1833 roku Garczyński spróbuje raz jeszcze włączyć się w wir rewolucyjnych wydarzeń. Wiązał on nadzieję z szykującą się wtedy rewolucją w Niemczech. Po jej wybuchu we Frankfurcie pisze Mickiewicz do Garczyńskiego: „Chciałbym puścić się gdzie z Paryża. Czekamy wypadków w Niemczech; i tu rzeczy długo stać nie mogą. Ale wy o Niemczech lepiej wiecie. Mam przeczucie dobre od niejakiego czasu i zdaje mi się, że wkrótce gdzieś coś ważnego zajdzie" (Paryż, 8 IV 1833; XV 66).

Wydarzenia te miały w najbliższym czasie ogarnąć Włochy i zapoczątkować rewolucję powszechną. 17 kwietnia Garczyński (zgodnie z typowo polskim wypatrywaniem szans dla

${ }^{10}$ A. E. Odyniec, Wspomnienia z przesztości opowiadane Deotymie [Jadwidze Łuszczewskiej], Warszawa 1884 , s. 394.

"M. Danilewiczowa, op. cit., s. 64. 
sprawy narodowej wszędzie tam, gdzie toczyła się walka o wolność) ${ }^{12}$ informuje Mickiewicza: „Tu i wszędzie w Niemczech spokojnie i spektaklu być nie może; ja na wschód patrzę” (Drezno, 17 IV 1833; s. 103) ${ }^{13}$. Na zawartą w tym liście propozycję spotkania Mickiewicz odpowiada: „Ale z widzenia się naszego nie wiem, czy co będzie! Trudno nam z miejsca ruszyć: pasportów nie ma, do Niemiec nie puszczają, a przekradłszy się trudno nazad wrócić! Finanse też w lichym stanie. Do Strasburga nawet doktrynery nas nie chcą puszczać i wszystkich stamtąd wyrugowali. Ja miałem projekta na Wschód, powierzam tibi soli i Edwardowi; ale pokój z Ibrahimem podobno mnie odejmie sposobność puszczenia się w tamte strony" (Paryż, 6 V 1833; XV 72). Z listu wynika, dlaczego wyjazd do Strasburga był niepewny. W 1833 roku „Ibrahim-Pasza, syn wicekróla Egiptu Mehemeda Alego, prowadził zwycięską wojnę z Turcją, popieraną przez Rosję. W tej sytuacji wielu polskich oficerów na czele z generałem Henrykiem Dembińskim pospieszyło w szeregi Ibrahima, aby walczyć przeciw jednemu z naszych zaborców. Garczyński wiedział o tych wydarzeniach i (...) gotów był razem z Mickiewiczem wziąć w nich udział, by wykorzystać jeszcze raz okazję służenia sprawie polskiej”" 27 maja prosił Garczyński Mickiewicza: „Gdybyś twego zamiaru z myśli nie wypuścił, poczekaj dwa miesiące przynajmniej. (...) Pojechalibyśmy razem" (Frankfurt, 27 V 1833; s. 106). Historia zdecydowała jednak inaczej, gdyż w czerwcu 1833 roku „pod naciskiem Anglii uczestnicy konfliktu przystąpili do pokojowych rozmów"15.

\section{3.}

Role romantycznych przyjaciół zakładały daleko nieraz idącą ingerencję w życie uczuciowe obiektu przyjaźni (np. rola filomatów w romansie Mickiewicza z Marylą Wereszczakówną czy też przyjaciół Zygmunta Krasińskiego w jego rornansie z Joanną Bobrową). Garczyński odegrał również taką rolę w przerwaniu modnego, „publicznego” romansu Mickiewicza z Konstancją Łubieńską, który został nawiązany latem i kontynuowany jesienią 1831 roku, podczas pobytu Mickiewicza w Wielkopolsce, zwłaszcza w Śmiełowie i Budziszewie. Konstancja, niezrozumiana przez męża - Józefa, zdecydowała się na związek z Mickiewiczem. We wrześniu tego roku poeta był ojcem chrzestnym jej czteroletniej córki - Marii Tekli. Jak pisze Zdzisław Szeląg, Łubieńska „opuściła (...) męża, czworo dzieci i w początkach marca [1832 roku] przybyła do Drezna z zamiarem połączenia się z Mickiewiczem"16. Sytuacja ta stała się kłopotliwa dla niego, gdyż Konstancja zdecydowała się na rozwód z mężem i ślub

\footnotetext{
${ }_{12}$ Zob. S. Skwarczyńska, Mickiewicz a rewolucja frankfurcka $w 1833$ r. (O nowe oblicze Mickiewicza $w$ latach 1832-1833), [w:] Zjazd naukotvy polonistów. 10-13 XII 1958, Wrocław 1960, s. 540.

${ }_{13}$ Cytaty z listów Stefana Garczyńskiego pochodzą w większości z wydania: Korespondencja Adama Mickiewicza, t. II, Paryż 1872 (oznaczane dalej nazwą miejscowości, datą i numerem strony). Korespondencję Garczyńskiego datuję za: Listami do Adama Mickiewicza w Muzeum Mickiewicza w Paryżu, opr. J. Odrowąż-Pieniążek, „Archiwum Literackie” t. 12, Wrocław 1968, s. 61-63.

${ }_{14}$ Z. Szeląg, Stefan Garczyński. Zarys biografii, Kielce 1983, s. 144.

15 Tamże.

16 Tamże, s. 117.
} 
z Adamem. Nie pomogło odtrącenie, gdyż „latem 1832 roku podjęła kolejną, nie ostatnią zresztą, próbę zniewolenia poety" ${ }^{\prime 17}$.

Trzeba zaznaczyć, że historię tego nieszczęsnego romansu znamy bardziej z listów Garczyńskiego niż Mickiewicza ${ }^{18}$.

Garczyński perswadował przyjacielowi bezsensowność tego związku. Już 25 sierpnia 1832 roku pisał do Mickiewicza: „Pani Ł... w Ems dopytywała się listami o twój pobyt mam nadzieję, że cię przecież molestować nie będzie"19. Kolejny, ważny dla konfliktowej znajomości Mickiewicza z Łubieńską list napisał Garczyński w październiku, po otrzymaniu listu od poety (nie zachowanego, najprawdopodobniej zniszczonego przez Władysława Mickiewicza). Pisał w nim:

„Chc(ę) ci dokładnie o krokach p. Ł. zdać sprawę. Wiedz, żc po dwutygodniowym pobycie w Dreznie wyruszyła do domu na koniec. Ma ona serce bardzo dobre, ale lekkomyślna i nicuważna. Będąc do tajemnicy przez nią samą przypuszczony, mówiłem z nią bez ogródek — zdawało mi się bowiem, że ona przez swój wyjazd — albo - Bóg ją tam wie przez co - rzecz rozmazała. Zdaje się, że ktoś trzeci (ma podejrzenie na kuzyna jakiegoś) listy twoje przejął — i tym sposobem na jaw wszystko wyszło. Cierpiała bardzo, byłem tego świadkiem. Odebrawszy listy uspokajające z domu, wyjechała dość wypogodzona już w domu być musi. Tak więc cała rzecz skończona — do pojedynku wątpię, żeby przyszło - znam szlachtę naszą. (...) Od Ł. mam niezabudkę, dla ciebie. Rozstaliśmy się bardzo dobrze, chociaż z początku kwaśno było, bo list twój, w którymś o chorobie z jej przyczyny donosil, dotknął mię mocno i nie żałowałem prawdy. W sekrecic przed tobą opowiadała mi rzecz całą, myśląc, że od ciebie nic nie wiem. Miała ona myśli różne i dziwne. Zbijałem ją kategorycznym sposobem. Kiedy o rozwodzie mówić poczęła, ja o nieszczęściu rozprawiałem; kiedy o obietnicach — ją o szlachetności duszy i ofiarach. Dosyć powiedzieć — zupełnie jej z głowy dawne wypadły projekta — pod koniec do dzieci tylko wzdychała, a o tobie jak o przyjacielu dozgonnym mówiła... Toć przyrzec jej musiałem, zmieniwszy pod koniec ton prawd w słowa pociechy, że ty o niej nie zapomnisz, a ja po przyjeździe do Paryża portret twój nadeślę.

${ }_{17}$ Tamże, s. 117-118. Zob. też: Z. Sudolski, Mitośc w życiu Mickiewicza - legenda i prawida. Maryla — Karolina - Konstancja - Ksawera, „Przegląd Powszechny” 1993 nr 2, s. 274-291.

18 „Wladysław Mickiewicz (...) cytuje odnośną korespondencję i materiały do tego romansu, skraca je w sposób godny syna, a nie biografa obiektywnego" (B. Zakrzewski, op. cit., s. 87). Wiele fragmentów dotyczących tego romansu zostało przez W. Mickiewicza opuszczonych w Korespondencji Adama Mickiewicza i w pierwszym wydaniu Żywota Adama Mickiewicza (t. 1-2, Poznań 1892). Dopiero drugie wydanie Żywota... (Poznań 1931) i następne wydanie Korespondencji uwzględniają pominięte fragmenty z listów Garczyńskiego - zob. J. Kleiner, Mickiewicz, t. 2: Dzieje Konrada, cz. 1, Lublin 1948, s. 233, przyp. 2.

${ }^{19}$ Stefan Garczyński do Adama Mickiewicza, Drezno, 25 VIII 1832, [w:] J. Maciejewski, Mickienvicza wielkopolskie drogi..., s. 477-478. To opuszczone zdanie opublikowała też M. Dernałowicz, Kronika życia i twórczości Mickiewicza. Marzec 1832 - czenuiec 1834, Warszawa 1966, s. 93. 
Otóż i pacta conventa, kochany Adamie: (...) Kocha ciebie biedaczka — i dlatego warto jej winy odpuścić..." 20 .

Dzięki interwencji Garczyńskiego skandal rodzinno-obyczajowy został załagodzony. Konstancja powróciła do męża i dzieci.

26 listopada jeszcze raz pisze Garczyński do Mickiewicza w tej sprawie: „Z p. Ł. wszystko mam nadzicję ukończone - przyszłych więc rzeczy nie bierz już do serca — dosyć cię namordowano..."21. Ale z korespondencji Garczyńskiego wiadomo, że Łubieńska wykorzystywała go do przesyłania pamiątek Mickiewiczowi i chciała uczynić pośrednikiem w odnawianiu romansu. Pisze on do Adama: „Posłałem (...) [ci] lornetkę ze złotym łańcuchem, czy odebrałeś?" (Drezno, 9 I 1833; s. 96). Tak więc nękający Mickiewicza romans, wydawało by się zażegnany, znów powraca w korespondencji. W jednym z listów do Garczyńskiego poeta pisze: „Często jestem zmęczony moralnie, wiesz z jakiej przyczyny. Nieszczęściem, dotąd nie mogę odpokutować i widzę chęć wplątania mię znowu koniecznie. Postanowiłem nic nigdy nie odpisywać. Nic też o tym nie gadaj i nie pisz nigdzie" (Paryż, 5 III 1833; XV 59). Poeta bronił się przed tym uczuciem, romansu nie chciał odnawiać.

Kolejne dyskretne wynurzenia Mickiewicza na temat pani Łubieńskiej są zawarte w liście do Garczyńskiego z 8 kwietnia 1833 roku: „Domeyko widział mnie nieraz głęboko smutnym, ale $z$ innych przyczyn, o których wiesz nieco. On myśli, że to bieda finansowa albo figle demokratyczne tak mię dotykają" (Paryż, 8 IV 1833; XV 66). Dlatego też jeszcze w tym samym miesiącu Garczyński odpowiada swemu przyjacielowi, nieelegancko dyskredytując moralność Konstancji Łubieńskiej: „Nie wiem, drogi mój Adamie, jak sobie możesz wyrzuty robić wspomnieniem z rzeczy, która nawet na pamięć nie zasługuje. P. Ł. jest to kobieta, którą każdy, co wiersze pisze, przewracać by mógł na prawo i na lewo. Zresztą ona tego bigosu nawarzyła. - Brzydką jest kokietką, nic więcej. Dobrze robisz, że nie pisujesz, ale i myśleć o niej grzechem, osobliwie tobie. Nikt jej pewno więcej prawd nie nagadał jak ja. Między innymi dowodziłem, że twego małego palca nie warta" ${ }^{22}$.

Zaś 14 maja tego roku Garczyński ujawnił Mickiewiczowi „własny romans z jakąś mężatką, napisał bez ogródek o ówczesnych sposobach kończenia takich przelotnych męskich przygód” "23. Oto co pisał: "Jeśliś ty wiele cierpiał z przyczyny p. Ł. , ja nie mniej z innej przyczyny. Alc o tym nie piśmiennie mówić. Wiedz tylko, że nasze dosyć podobne stosunki były, dlatego Drezno z ukontentowaniem opuszczam" (Drezno, 14 V 1833; s. 105). Jest to

\footnotetext{
20 Stefan Garczyński do Adama Mickiewicza, Drezno, 26XI 1832, [w:] R. M. B. [R. M. Blüth], Nieznany list Stefana Garczyńskiego do Adama Mickiewicza w sprawie Konstancji Eubieńskiej, „Ateneum” 1938 nr 6, s. 962.

21 Tamże, s. 963.

${ }^{22}$ Stefan Garczyński do Adama Mickiewicza, Drezno 17 IV 1833, [w:] J. Kleiner, op. cit; ;. Maciejewski, op. cit., s. 189-190.

${ }^{23}$ J. Macicjewski, op. cit., s. 190.
} 
ostatnia wzmianka o Łubieńskiej w korespondencji poetów. W tym momencie romans Mickiewicza z panią Konstancją zakończył się, przyjaźń zachował poeta do końca życia ${ }^{24}$.

Mówiąc o korespondencji, warto wspomnieć, że już po śmierci Mickiewicza Łubieńska wydała w 1863 roku w Poznaniu broszurę Listy śp. Adama Mickiewicza do pani Konstancii, gdzie zebrała „(...) 21 listów poety pisanych w latach 1845-1855, w których Mickiewicz przedstawił się jako żarliwy katolik, kaznodziejskim niejednokrotnie tonem interpretujący wydarzenia i zalecający w osobistym życiu postępowanie pełne chrześcijańskiej pokory, skromności, wyrzekania się przyjemności doczesnych i materialnych korzyści, ciągle mając na ustach przykłady ewangeliczne, które były jednocześnie wyrazem prawdziwego, nieagitacyjnego demokratyzmu”25.

\section{4.}

Garczyński długo nie wspominał Mickiewiczowi o tym, że pisze wicrsze. Targały nim niepewności, jak to odbierze jego przyjaciel. W końcu postanowił ujawnić swój talent. Staje się to dopiero podczas pobytu obydwu w Wielkopolsce. W Objezierzu spotyka się Mickiewicz z Garczyńskim, który wtedy zdradza się przed nim z umiejętnością pisania wierszy. Zdarzenie to miało miejsce w majątku Heleny i Wincentego Turnów po Nowym Roku $1832^{26}$. Zasłużony wydawca materiałów dotyczących Garczyńskiego, Zdzisław Szcląg, nazywa tę informację „bałamutną”, pisząc wprost: „Przede wszystkim Garczyński nie mógł tak długo ukrywać swoich twórczych zainteresowań choćby dlatego, że był autorem utworów publikowanych w powstańczej prasie oraz dwóch ulotnych druczków. Wincenty Turno

\footnotetext{
${ }^{24} \mathrm{Na}$ ślad istnienia Konstancji Łubieńskiej w późniejszym życiu Mickiewicza zwraca uwagę J. Maciejewski, op. cit., s. 192 (list poety do Odyńca z 18 lipca 1836 roku). Jej postawa wprawiała Mickiewicza w wielkie zakłopotanie, gdyż dopominała się o jego listy, jak też próbowała wspierać go materialnie: „P. Ł. jeśli dotąd jest w Dreźnie, oświadcz, iż ma niesłuszne bardzo podejrzenia i fałszywie sobie wystawia mój charakter i sposób myślenia. Stosunki wszelkie między nami muszą ustać przez wzgląd na nasze zobopólne położenie! P. Ł. pisała do mnie o jakichś posyłkach. Odebrałem niedawno fr. 250 przez bankiera z krótkim tekstem podpisanym "Adam» i z oświadczeniem, iż to dług dawny. (...) Nie wpatrzywszy się w charakter, myśliłem, że Rajecki jaz odsyła. Wystaw moje zadziwienie, kiedy teraz widzę z kartki p. Ł., skąd ta suma pochodzi. Jeżeli nowe posyłki tego rodzaju przyjdą, nie będę ich odbierał. Przełóż, proszę, p. Ł., w jak przykrym stawi mnie położeniu" (Domont, 18 VII 1836; XV 163).

Następne zdanie tego listu - co zauważył Jarosław Maciejewski - jest próbą identyfikacji Łubieńskiej z postacią Telimeny z Pana Tadeusza. Skojarzenie to narzuciło się jej samej: „To, co piszesz o Telimenie, śmieszne i dziwne! Jakież tam może być podobieństwo! Zresztą już do wielu osób stosowano, a niektóre same do siebie stosowały, chociaż w istocie o żadnej z nich nie myśliłem pisząc" (tamże).

${ }^{25}$ J. Maciejewski, op. cit., s. 176-177, 471 przyp. 10. Publikacje tę zaopatrzyła Eubieńska notką wstępną: „Własnoręczne listy śp. Adama Mickiewicza, z przyjacielskiej korespondencji, z czasów i wypadków ubiegłych świeżo, i z rad sumiennych udzielanych, jako przyjaciela, w zasadach duszy rzetelnie chrześcijańskiej podajemy Polakom dla zapoznania ich niegdyś wieszcza, ulubionego w Jego zawodzie życia dalszym, które to listy na dochód Towarzystwa Dobroczynności poświęca Konstancja" oraz oświadczeniem w zakończeniu broszurki: „Niniejsze listy z wieloletniej korespondencji, które jeszcze w takiej ilości pozostały, jako drogie pamiątki drukiem ogłoszone, czci należnej śp. Adamowi Mickiewiczowi, jako w dowodzie jego zasad najwznioślejszych poświęca prawa przyjaciółka, zastrzegając sobie z tych listów przedruku w żadnym innym piśmie. Konstancja".

${ }^{26}$ Z. Stajewska, „Wactawa dzieje” Stefana Garczyńskiego, Wrocław 1976, s. 23; zob. też: J. Maciejewski, Gdy gościt w Wielkopolszcze. Adam Mickiewicz w Wielkim Księstwie Poznańskim 1831-1932, Poznań 1958, s. 166.
} 
posiadał nie tylko owe druczki, ale i odpis wiersza powstańczego oraz dwa fragmenty poematu [Wactawa dzieje]"27. Zdaniem badacza, o poetyckich zainteresowaniach Garczyńskiego wiedzieli też jego towarzysze broni Arsen i Leonard Kwileccy, którzy to mogli wówczas przebywać w Objezierzu, i dlatego „trudno w tych okolicznościach przyjąć, aby Mickiewicz nic nie wiedział o pracy poetyckiej przyjaciela, i aby ten nie przeczytał mu swych utworów (mieszkali razem). Co ważniejsze, zachowały się ślady twórczej pracy Garczyńskiego z tego okresu. 16 grudnia, a więc w dzień po przyjeździe Mickiewicza do Objezierza, napisał wiersz Zapaleniec mtody" 28 .

Szeląg jakby nie zwraca uwagi na dwie ważne informacje źródłowe. Pierwszą z nich jest przytoczone przez Bronisława Gubrynowicza opowiadanie Heleny Turno:

Przepędziwszy Wigilię Bożego Narodzenia w Łukowie, przyjechał pan Adam Mickiewicz na Nowy Rok do Objezierza. Tu zastał Stefana Garczyńskiego, który mu się dopiero wtedy przyznał, że pisze poezje i przeczytał mu swojego Wactawa w manuskrypcie. Obaj mieszkali razem w małej oficynie obok pałacu. Garczyński czytał, pan Adam słuchał, chodząc po pokoju i puszczając kłęby dymu tureckiego. Spowiedź ta poetycka odbyła się w nocy z początkiem Nowego Roku. Pan Adam bardzo był Wacławem uniesiony i nazajutrz powiedział żartobliwie do pani domu: „A to pięknie, zaprosiła mnie pani do Objezierza, aby mnie tu z Parnasu strącili"29.

Drugą z nich jest niewątpliwie list Mickiewicza do Joachima Lelewela wspominający o tym, że nieśmiały poeta długo nie zdradzał się przed swym przyjacielem z twórczości poetyckiej, nawet w Rzymie, dokąd przyjechał z początkiem marca 1830 roku. Czytamy w nim: „Rewolucja wydała poetę swego, nieznanego jeszcze. Jest to Garczyński; dwa lata znałem go w Rzymie, a nic mi nie czytał i nie wiedziałem, że pisze" (Drezno, 23 III 1832; XV 16) ${ }^{30}$.

Szeląg zauważa też, że Garczyński w czasie swego pobytu w Objezierzu rozmawiał na temat możliwości wydania swych poezji. Zamierzał on drukować je w Poznaniu, zapewne w wydawnictwic Juliusza Adolfa Munka. Chciał drukować Wacława, ponieważ wiersze

\footnotetext{
${ }^{27}$ Z. Szelagg, op. cit., s. 107.

${ }^{28}$ Tamże.

${ }_{29}$ B. Gubrynowicz, Kartka ze wspomnień o pobycie Mickiewicza w Poznaniskiem, „Kwartalnik Historyczny” 1898 z. 4, s. 843-848.

${ }_{30}$ Na ten list zwracają uwagę: W. Mickiewicz, Żywot Adama Mickiewicza, t. 2, Poznań 1892, s. 99, 180; B. Gubrynowicz, op. cit.; B. Zakrzewski, Mickiewicz w Berlinic, „Przegląd Zachodni” 1949 nr 3-4, s. 181-192. $\mathrm{Nb}$. Antoni Edward Odyniec we: Wspomnieniach z przesztości opowiadanych Deotymie, op. cit., s. 389-191, pisze, że w połowie stycznia 1831 r. w gościnie u Ewy Dobrzyckiej w Dreźnie Garczyński wyjawił mu swą wielką tajemnicę: „Ja piszę wiersze!” Radość Odyńca wzbudziła „skończona forma artystyczna tych wierszy, należących do poematu Wactawa dzieje, który wówczas nosił tytul Apostata. Dalej Odyniec prosi Garczyńskiego, „żeby [mu] pozwolił napisać o tym do Adama; lecz on [mu] owszem wyraźnie i stanowczo tego zabronił". Informacje Odyńca nie zawsze zasługują na wiarygodność, w tym wypadku jednak, jak sądzę, nie ma podstaw do nieufności wobec autora Wspomień.
} 
obozowe nie mogły być drukowane w Poznaniu ze względu na cenzurę i dlatego Turnowie radzili mu przesłać je do Paryża 31 .

Niemal całe drugie półrocze 1832 roku, w chwilach lepszego samopoczucia, wykorzystywał Garczyński na przygotowanie swych utworów do druku. Bardzo pragnął obejrzeć tę edycję jeszcze przed śmiercią. Czystopis Wacława ukończył 18 sierpnia, a 25 sierpnia zawiadomił Mickiewicza: „Ja Wacława część pierwszą skończyłem, trzeba tylko poprawić gdzieniegdzie, przepisać, twojej aprobacji, a tak rzecz wygotowawszy, jeżeli i pieniądze będą po temu, w obieg puszczę" (Drezno, 25 VIII 1832; s. 91). Jak bardzo Garczyński liczyl się zc zdaniem Mickiewicza, świadczy list z 16 października tegoż roku, w którym donosi mu, iż po Wacłauie niczego jeszcze nie napisał. Pisze „Potrzeba mi twego stempla. Chciałbym ci to co nie znasz z Wacława przeczytać" (Drezno, 16 X 1832; s. 91). Czystopis przeznaczony do druku sporządził Garczyński do 26 listopada, o czym informował Mickiewicza: „Poezje moje przepisałem. Wacław obszerny, ale nie wiem, czy w nim zasmakujesz, gdzieniegdzie są myśli, ale, ale... przepisując nie wiem dlaczego gust-em do niego utracił. Dwie części tak jak się udały zostać muszą, w dalszych lepiej może pójdzie. (...) Wspomnienia obozowe uzupełnione już prawie zupełnie (...) np. Na dzień 29 listopada ale toć sam osądzisz. Koniec końcem, przeszlę ci wszystkie moje wiersze, jeśli odpiszesz a to spiesznie, że i sam pomocy w wydrukowaniu nie odmówisz i kogoś szczegółowo wybierzesz, który by się tym zajął” (Drezno, 26 XI 1832; s. 93).

Odpowiedź Mickiewicza musiała nadejść dość szybko (list niestety nic zachował się), skoro już 7 grudnia przekazał Garczyński pakiet rękopisów Klaudynie Potockiej, która wysłała go do Paryża przez byłego członka rządu powstańczego — Stanisława Barzykowskiego.

Garczyński myśląc o wydaniu Poezji nie chciał tego uczynić bez „aprobacji” i "stempla” przyjaciela. Zdawał sobie sprawę, że jego wiersze wymagają poprawek „mistrza”. Krępował się jednak bezpośrednio zwrócić się o korektę i dlatego w grudniowym liście informował go, że zwrócił się w tej sprawie do Domeyki i Witwickiego, „bo nie czesać i myć dzieci [Adamowi]" (Drezno, 7 XII 1832; s. 94).

Odpowiedź Mickiewicza nie nadchodziła dość długo, co niepokoiło Garczyńskiego. „Nie wiem, co się to znaczy — pisał na początku następnego roku — że od ciebie tak długo listu nie odbieram. Przed pięciu tygodniami wyprawiła pani Potocka (...) pakiet, [który zawierał] z wielką pracą przepisane poezje moje. Czy by zaginęły? nie wszystko mam w brulionie, szkoda by było. Wierzę prawda w przeznaczenie, niespokojny jestem przeciez" (Drezno, 9 I 1833; s. 95-96). Autor listu oczekiwał niecierpliwie na zdanie swego przyjaciela o poezjach, szczególnie zaś o drugiej części Wacława. Prosił o natychmiastową odpowiedź. W liście tym pytał również: „czy by dobrze było przemowę jaką krótką o poezji tegoczesnej na czoło poezyj (...) wystawić?” (tamże, s. 97), wyrażając chęć przesłania jej.

Mickiewicz otrzymał rękopisy dopiero 11 stycznia 1833 roku: „Wczora, ledwie wczora odebrałem twój rękopism!" (Paryż, 12 I 1833; XV 54). Szczególnie silne wrażenie wywarły

${ }^{31}$ Z. Szeląg, op. cit., s. 109-110. 
na nim Wacława dzieje: „Czytałem cały wieczór Wacława. Wrażenie zrobił na mnie większe nad wszystkie moje nadzieje o nim. Kiedyś czytał niektóre części, zdawały się nie dokończone albo namieszane, ale w ciągu harmonizują się i stanowią całe indywiduum. Już nie radziłbym odmieniać tego, co dawnej bym odmieniał" - Mickiewicz posuwa się nawet do tego rodzaju pochwały poezji Garczyńskiego: „Mnie się zdaje, że gdyby Wacław był nie twoim utworem, to bym może zazdrościł autorowi. Teraz kocham go jak gdyby wspólne dziecko" (tamże). Radzi jednak zmienić dedykację ${ }^{32}$, a zwłaszcza jej pierwsze trzy wyrazy, oraz poleca poprawić pieśń o pchle, bo zbyt przypomina taką samą z Fausta Gothego, a właściwie jest jej przekładem. Chwali jednocześnie pieśń Nieznajomego o szczurach, proponując w niej tylko nieliczne zmiany. Obiecuje też szybkie rozpoczęcie druku poematu, zachwycając się nim raz jeszcze: „Od dawnych lat, od czasu kiedym czytał Szyllera i Bajrona, nic mię [tak] głęboko całego nie zajęło! (...) jeśli masz wenę, pisz koniecznie dalej” (tamże, s. 55).

Wzajemnie Mickiewicz w tym samym liście zawiadamia, że napisał już „dwie pieśni” z Pana Tadeusza, którego brulion wraz z broszurką Ksiag pielgrzymstwa zamierza przesłać przyjacielowi.

O swojej aktualnej pracy pisał pocta do Antoniego Edwarda Odyńca w liście z końca stycznia 1833 roku: „Stefka poezje teraz do druku gotują, tu i ówdzie wyrazy przestawiam i łagodzę. (...) teraz Giaura przepisuję i z wielkim żalem musiałem poema szlacheckie zawiesić" (Paryż, 28 I 1833; XV 56-57).

Mickiewicz bardzo zaangażował się w edycję dzicła ciężko chorego i dogorywającego Garczyńskiego. Rzecz to niezwykła, zważywszy, że „nienawidził drukarskiej korekty. Czasami się zdarzało, że w ogóle nie robił ani jednej korekty swego dzieła (np. pierwodruku Grażyny), a z reguły nie robił wszystkich korekt drukowanego utworu, spychając, ile się tylko dało, całą robotę na pomocników"33.

Mickiewicz wszczął zabiegi wydawnicze wobec poezji Garczyńskiego. Jak pisze Zdzisław Szeląg, „druk polskiej książki w Paryżu nie był łatwy i to tak z uwagi na płodność pisarską emigracji, jak i brak dostatecznej liczby oficyn wydawniczych posiadających polskie czcionki. (...) Uwzględniając sytuację materialną Garczyńskiego, Mickiewicz po naradzie z Ignacym Domeyką (12 stycznia) postanowił wydać Poezje przyjaciela możliwie najtaniej i szybko”³4.

Zniecierpliwiony Garczyński chciał ujrzeć jeszcze przed spodziewaną śmiercią swoje wiersze w druku. Ponagla Mickiewicza, gdyż „w Księstwie prenumeratorowie niecierpliwią się i co moment o książki dopytują" (Drezno, 25 II 1833; s. 98), a ponieważ, jak przypuszczał, wszystkie utwory nie zmieszczą się w jednym tomie, chciałby w pierwszym Wactawa i „wiersze różne, w drugim sceny fantastyczne, wspomnienia i sonety umieścić” (tamże, s. 99). Zwierza się też Mickicwiczowi, iż jego Ksieggi pielgrzymstwa zachwyciły go i „uczy się ich jak

\footnotetext{
32 „Mistrzowi poetów polskich Adamowi Mickiewiczowi na pamiątkę kilku miesięcy w roku 1831-go razem w Dreźnie przepędzonych poświęca przyjaciel dozgonny"

${ }^{33}$ K. Górski, Tekstologia i edytorstwo dziet literackich, Warszawa 1975, s. 33.

${ }^{3+}$ Z. Szelag, op. cit., s. 137.
} 
ewangelii na pamięć", mając jednocześnie ich autorowi za złe, że się na nich nie podpisał. Informuje go też, iż zachwyca się czytanym w oryginale Byronem i może „Wacława bylby lepiej, mocniej napisał, gdyby wprzódy był znał tego arcymistrza" (tamże, s. 100).

W pierwszych dniach marca 1833 roku Mickiewicz zdecydował się pod wpływem nalegań autora Wacława wydać Poezje swego przyjaciela u Pinarda, ponieważ był to największy spośród posiadających polskie czcionki dom wydawniczy w Paryżu: „Wiesz zapewne przyczynę zwłoki druku, którego tak jesteś niecierpliwy; pojmuję dobrze niecierpliwość, lubo teraz, jak ojciec wielu dzieci, już mniej dbam o ich urodziny i chrzciny, a twój Wacław więcej mnie teraz obchodzi niż moje własne dzieło" (Paryż, 5 III 1833; XV 59).

Mickiewicz prowadził też równolegle inne korekty, o czym donosił Garczyńskiemu: „Zajęty byłem mocno i znudzony przepisywaniem i poprawą Giaura, jeszcze nie skończonego; muszę kończyć i przedawać, i to mi przerwało moje poema wiejskie, które bardzo lubię; Giaura już zbrzydziłem" (tamże, 59-60). Poeta nie wspominał zaś ani słowem o tym, że praca korektorska nad poezjami Garczyńskiego odrywała go od pisania Pana Tadeusza. Świadczy to o delikatności wobec przyjaciela, którego uważał za swego ucznia i którego utwory lansował.

W liście z 17 marca Garczyński, tworzący w okresie nasilania się choroby resztkami sił, byle jego praca ujrzała jak najszybciej światło dzienne, donosi Mickiewiczowi, że posyła mu wiersze, w których rzekomo „nie ma nic osobliwego”, ale mile autorowi, bo je „krwią okupił”. „Jeśli za niezłe osądzisz, będzie je można między wierszami umieścić różnymi” (Drezno, 17 III 1833; s. 100-101).

8 kwietnia 1833 roku przesłał Mickiewicz Garczyńskiemu wyrazy zachwytu nad otrzymanym wierszem: „Odebrałem twój hymn, który należy do najpiękniejszych twoich i naszej literatury tworów" (Paryż, 8 IV 1833; XV 65). Po tej pochwale wiersza o incipicie Piersi moje zbolate... przechodzi poeta do omówienia spraw druku poezji przyjaciela: „Pierwszy twój arkusz już wyszedł z powtórnej korekty. (...) Domeyko chodzi i jak może napędza, ale druk pewnie dwa miesiące potrwa. Zresztą epoka ogłoszenia szczęśliwa bardzo. Nie będą mieli czasu recenzenci drobnostkowymi uwagami oślinić dzieło. Nikt teraz nie myśli o szlifowaniu wierszy i mikroskopowaniu wyrażeń. A twoje poezje właśnie całością uderzą. (...) Słowem, Opatrzność wyda dzieło twoje nie pierwej i nie później, jak potrzeba. Niektóre poezje drobne puszczę w dziennik «Pielgrzyma» w którym piszę artykuły. Osobno zrobię uwagi nad całym dziełem. Sonety niektóre wyrzucę. W ogólności sonety (wyjąwszy dwa) mniej mi podobają się, bo w małych ramkach rażą tu i ówdzie szczegółami" (tamże; s. 65-66) ${ }^{35} \mathrm{~W}$ tym samym liście oprócz rad i pochwał wspomina Mickiewicz też o swojej pracy: „Giaura szelmę i nudnika skończyłem przepisywać; zjadł mi więcej miesiąca. Wracam do Szlachcica [tj. Pana Tadeusza - G. S.] i piszę czasem do dalszych Dziadów [niedochowanych - G. S.]. Księgi

${ }^{35}$ Mickiewicz dopiero 18 X 1833 w „Pielgrzymie Polskim” zamieścił wiersz Garczyńskiego pt. Śpiew po zwyciestwie pod Stoczkiem, recenzji zapowiedzianej nie napisał. (zob Wydanie Jubileuszowe t. XV, s. 67, przyp. 3). 
pielgrzymstwa już tu wyszły dawno" (tamże). Zapewnia także przyjaciela, że w razie potrzeby może pożyczyć kilkaset franków na druk jego poezji.

W dwa tygodnie później Garczyński pisał do Mickiewicza: „Tu w Dreźnie poezji moich czekać chciałbym. (...) Jeśli niektóre sonety wyrzucisz, czego wcale nie wzbraniam, dobrze by może było pompatyczny tytuł Sonetów wojennych na Próby sonetów wojennych przemienić. Zresztą rób jak ci się wydawać będzie. Do „Pielgrzyma” podawaj co zechcesz, za uwagi nad całym dziełem wdzięcznym ci bardzo będę" (Drezno, 17 IV 1833; s. 102). Dalej omawia szczegóły poprawek w Wacława dziejach, po czym prosi „kochanego Żegotę [Domeykę], żeby wierszy drukarzom wypuszczać nie pozwalał, w ćwiartce próby bowiem (...) nadesłanej całego wiersza: “Ustami proch całują, rozpostarł się krzyżem» brakuje” (tamże).

21 kwietnia pierwszy tomik Poezji Garczyńskiego był już odbity, drugi odbijano, a trzeci składano, o czym Mickiewicz zawiadamiał Odyńca, dodając: „dobrą jest wróżką, że mi jego Waclaw coraz więcej podoba się, szczególnie część ostatnia. Są tam pyszne rzeczy" (Paryż, 21 IV 1832; XV 69).

6 maja przesłał Mickiewicz Garczyńskiemu, który zaczyna już zadręczać wszystkich błędami, jakie dostrzega w druku swych poezji, wiadomość o skończeniu drukowania pierwszego tomiku Poezji oraz o tym, że korektę drugiego już przeprowadzono, po czym donosił przyjacielowi: „Starałem, co można, zrobić interpunkcją troskliwą. Wiele uwag i popraw wynotuję na osobnym egzemplarzu do przyszłej edycji; podam pod twój sąd, bo sam tego robić nie śmiałem. (...) Masz wiedzieć, że sam robiłem wszystkie korekty, czego dla własnej poezji nie zdołałem podjąć się. Musisz tedy mi podziękować, bo niemałą przywiązuję wagę do takiej pracowitości; rzadko w życiu dałem jej dowody. Domeykowi adres podziękowania za chodzenie do drukarni i przypędzanie zecerów!" (Paryż, 6 V 1833; XV 72). Widać tu, jak wiele kosztowało Mickiewicza przygotowanie tych poezji do druku, skoro wreszcie ośmielił się wytknąć to niecierpliwiącemu się przyjacielowi. W tym samym liście proponował też poprawki w drugim tomiku - usunięcie z niego niektórych wierszy, zwłaszcza ballady Przestroga, oraz własnąjednowierszową wstawkę do rozdziału trzeciego części drugiej Wactawa dziejów:

Uchem rozezna wyrocznych kół grzmienie,

\section{Wskoczy w rydwan wyroków i zajmie siedzenie,}

I przyjedzie po czasie jako przeznaczenie -

„bo w tym pięknym kawałku jest wiele ciemności, są rysy kilku obrazków nie skończonych. Po grzmieniu kół następuje "przyjedzie po czasie» etc. Długo nie śmiałem zrobić tej poprawy, ale po naradzie z Witwickim uczyniłem ją" (tamże; s. 73). Wspomniał również o nie spełnionym nigdy projekcie napisania recenzji pierwszego temu poezji w „Pielgrzymie Polskim”, jak też o własnej pracy pisarskiej: „Skończyłem trzecią pieśń Tadeusza. Zanosi się na długą chryję, dotąd dosyć dobrze udaje się! Gdyby nie tyle przeszkód, gdyby jeden tydzień przeszłorocznej ciszy!” (tamże). 
Wiadomość o trudzie Mickiewicza-korektora przyjął Garczyński z zażenowaniem i wyrzutami sumienia: „To wszystko nie na twoją głowę, kochany mój Adamie, dlatego Żcgotę osobnym bilecikiem o zajęcie się i przyspieszenie rzeczy proszę. Za prowadzenie mozolne korekty każesz sobie dziękować. Czuję całą duszą poświęcenie się twoje, ale na dziękowanie słów brakuje, kochany mój Adamie. (...) Gdyby trochę zdrowia było, pospieszyłbym zaraz na te parę tygodni do Paryża, ażeby tobie i Domeyce pracy ująć" (Drezno, 14 V 1833; s. 104). Pyta też o losy stu egzemplarzy drukowanych jego poezji, które chciał rozsprzedać w Paryżu, Lipsku i Dreźnie. Domaga się również od Mickiewicza uwag recenzenta, obiecanych wcześniej, które miały ukazać się na łamach „Pielgrzyma Polskiego”, a pod koniec listu wspomina o tym, że chciałby bardzo czytać Tadeusza — „wzbudziłby może uśpioną duszç lekarstwami” (tamże; s. 105).

Aby uspokoić swego przyjaciela, Mickiewicz odwoływał swą poprzednią wypowiedź o ciężkiej pracy korektorskiej, obracając ją w żart i bagatelizując. Pisał w swym ostatnim zachowanym liście do Garczyńskiego 23 maja 1833 roku: „To, co pisałem o mojej pracowitości w korekcji, i moje przechwałki były żartem; jak ty to mogłeś brać serio? Korckta, wierz mi, że często robiła mi wiele przyjemności, bo zdawało mi się, że z twoją duszą gadałem, niekiedy dysputowałem, kłóciłem się, a zawsze, jak i w życiu naszym, rozstawaliśmy się w zgodzie" (Paryż, 23 V 1833; XV 74-75). W tym samym liście donosi przyjaciclowi, że kazał oprawić tom pierwszy jego poezji ${ }^{36}$ i zapowiadał wydanie drugiego razem z Reduta Ordona na końcu ${ }^{37}$ za parę tygodni. Poeta chwali również w nim styl otrzymanego niedawno wiersza Piersi moje zbolałe..., proponując poprawki „nie jako poeta, ale jako chrześcijanin”. Chodzi tu o wers: „Burzliwy - mówią - wieczór, gdy burzliwe rano”. Mickiewicz każe młodszemu koledze rozumieć przyszłość nic jako „wieczór”, gdyż ludzie „są posłani” po to, aby „wnicść światło w lepszą przyszłość”. W tej wypowiedzi zauważamy wyraźne ślady myśli z Ksiqg narodu polskiego i pielgrzymstwa polskiego.

${ }^{36}$ Egzemplarz ten przechowywany jest w Bibliotece Kórnickiej Polskiej Akademii Nauk, zob. prace Stanisławy Jasińskiej: Pamiątka po Stefanie Garczyńskim, „Pamiętnik Biblioteki Kórnickiej” 1946 s. 299-301; Oprawa „mickiewiczowska”, tamże, 1958 s. 370-374. Autorka pisze, że „druk został ukończony w lipcu 1833. Oprawiony egzemplarz wysłano Garczyńskiemu do Genewy między 2 a 8 sierpnia, a ten ofiarował go Klaudynie Potockiej, wpisując na karcie ochronnej wiersz dedykacyjny. Jasińska zaznacza, że oprawa „wykonana została bardzo solidnie pod każdym względem: przycięcie, szycie, klejenie, wycisk i złocenia są bez zarzutu. Skromna w wyglądzie, nie pozbawiona jednak pewnej dozy wykwintu i elegancji, jest ładnym i ciekawym okazem oprawy z drugiej ćwierci XIX wieku - oprawy romantycznej".

${ }^{37}$ Zagadnieniu temu poświęcone jest studium Samuela Sandlera "Reduta Ordona” w życiu i poezji. Gawę̧da historyczno-literacka, Warszawa 1956. Autor przypomina tam znany powszechnie fakt, że Reduta Ordona była rezultatem opowiadań Stefana Garczyńskiego — adiutanta generała Jana Nepomucena Umińskiego, dlatego Mickiewicz nazywał swój wiersz „wspólną własnością” (s. 24). Sandler zaznacza, że w końcu 1833 roku „do rąk emigrantów polskich, wychodźców po upadku powstania listopadowego, dostał się drugi tom Poezyj (...) Garczyńskiego. Tu czytelnik znajdował wiersz (...) zatytułowany Reduta Ordona [i] przypisek: «Wiersz ten, pisany pod wpływem opowiadań Garczyńskiego, umieszczam między dziełami przyjaciela jako wspólną naszą własność. Poświęciłem go ostatniemu wodzowi polskiemu, który o sprawie naszej nie rozpaczał i do końca chciał walczyćs"(s. 29). Sandler określa Redute - utwór popowstaniowy okresu drezdeńskiego - jako "najwyższy szczyt poetycki, osiągnięty w heroizacji czynu, działania, walki w obronie życia narodu” (s. 87). 
Zanim otrzymał list Mickiewicza z 23 maja, pisał do niego Garczyński jeszcze dwukrotnie. W pierwszym z nich, wysłanym z 27 maja z Frankfurtu, prosił o nadesłanie dziesięciu egzemplarzy tomu pierwszego jego poezji i ewentualnie kilka tomu drugiego, a także raz jeszcze o uwagi na temat jego poezji, które miały być drukowane w „Pielgrzymie Polskim” oraz „o nowe Słowackiego i Gaszyńskiego poezje”, których jest „głodnym i łaknącym” (Frankfurt, 27 V 1833; s. 106). W drugim zaś wysłanym ze Strasburga 5 czerwca prosił o odpowiedź na jego wszystkie „artykuły (...) wynumerowane”w poprzednich listach, ewokujące wskazówki mistrza do pracy poetyckiej (tamże; s. 107). Ponownie domagał się przysłania dziesięciu egzemplarzy Wacłau'a oraz egzemplarza drugiego tomu poezji, o ile został już wydrukowany.

O tym, jak żywo Mickiewicz interesował się wydaniem dzieł Garczyńskiego, świadczą poświęcone im dwa jego listy-komunikaty do Ignacego Domeyki, postulujące zmiany w wierszach Więzień, Na rocznicę i Król i giermek (Paryż, druga poł. VI 1833; XV 81-82).

5 lipca wyjechał Mickiewicz do Bex w Szwajcarii nad Jeziorem Genewskim, aby tam spotkać się z coraz bardziej chorym Garczyńskim, rezygnując z dalszej pracy nad Panem Tadeuszem $^{38}$ i przekazując Domeyce pieczę nad kończącym się drukiem drugiego tomiku Poezji Garczyńskicgo ${ }^{39}$. Przebywający w Bex, a następnie w Genewie autor Wactawa dziejów niepokoił się z powodu przedłużania się druku drugiego tomu jego wierszy. Irytowały go zniekształcenia tekstu, w związku z czym snuł różne domysły. Dlatego Mickiewicz pisywał często do czuwającego nad korektą Ignacego Domeyki, dając mu coraz nowe wskazówki: „Ale, ale, ale, na miłość boską, czy przepatrzyłeś dobrze korektę w sonecie Garczyńskiego Kanonier ostatni? Wiersz ostatni braknie, dopisz go wedle manuskryptu” (Bex, 9 VII 1833; XV 88). 27 lipca zaś pytał: „Czy wysłałeś tom pierwszy Garczyńskiego? tom drugi czy wyszedł? Nie uwierzysz, jak Stefan o to troszczy się, ustawicznie o tym myśli; lęka się, aby w Poznańskiem nie wzięto go za oszusta, a znowu ma podejrzenie, że po moim wyjeździe ty wszystko w kąt rzucisz i zajmować się nie zechcesz. Trzeba tedy kochanego dziwaka uspokoić” i prosił „Jeśli druk skończony, przyszlij nam tu kilka egzemplarzy” (Genewa, 26 lub 27 VII 1833; XV 89).

Także 2 sierpnia jeszcze raz wracał do tej sprawy: „Zmiłuj, dla uspokojenia Stefana każ wydrukować jego korekty, choćby do kilku tylko egzemplarzy. Trzeba znać jego choroby, żeby pojąć, ile on nad każdą omyłką rozpacza, jakie mnie robi wyrzuty i jakie dziwaczne ma podejrzenia. Dowiedział się, że egzemplarze są w Dreznie i jeden tu w Genewic, stąd nowe żale i domysły; przyszlij nam tu co rychlej kilka egzemplarzy. Oby się już ta historia drukarska skończyła, z którą miałem tyle biedy" (Genewa, 2 VIII 1833; XV 91).

Wkład Mickiewicza w druk Poezji Garczyńskiego wykracza poza kwestie redakcyjne, wiąże się też ze sprawami finansowymi. W momencie ukończenia druku tomu drugiego

\footnotetext{
${ }^{38}$ Pisał o tym z żalem do Antoniego Edwarda Odyńca: „Tadeusza dotąd nie dośpiewałem! Na nieszczęście, nie wiem, czy tu będę miał humor śpiewać dalej. Wszakże mam już trzy czwarte poematu, najdłuższego, jaki napisałem" (Bex, 9 VII 1833; XV 84).

39 Zob. Z. Szelag, op. cit., s. 146.
} 
Mickiewicz sfinansował część jego kosztów. Uregulowanie należności powierzył Ignacemu Domeyce w cytowanym liście z 9 lipca: „Przyszli, proszę, budżet drukarski; jeśli co braknie pieniędzy, załóż na moje konto i egzemplarze wyślij pod adresem: à Brockhaus à Leipsig. We środku adres: à Madame la Comtesse Claudine Potocka, à Dresde”.

Klaudynie Potockiej, która wywoziła Garczyńskiego z Drezna do Szwajcarii w maju 1833 roku i razem z Mickiewiczem czuwała nad umierającym młodzieńcem, w listopadzie 1833 roku poeta donosił: „koszta wydania dzieł Stefana opłacone zupełnie; rachunków nie posyłam (...), bo z kwitami razem wielką robi (...) pakę. Czekać będę okazji” (Paryż, między 16 a 20 XI 1833; XV 106) ${ }^{40}$. „Rozliczył się” przez to z redakcyjnego obowiązku wobec swego młodszego, nieżyjącego już wtedy kolegi-poety ${ }^{41}$.

\section{5.}

Stefan Garczyński, jak wiadomo, był od wczesnych lat młodzieńczych dotknięty chorobą gruźliczą.

Szczególnie drugie półrocze 1832 roku było dla niego okresem, w którym zdawał sobie często sprawę z tego, że niewiele mu już życia pozostało. Jego listy do Mickiewicza pisane w okresie rozwijającej się śmiertelnej choroby były gorzkie i jakby znaczone przeczuciem rychłej śmierci. Jeszcze w tych z wczesnej jesieni 1832 roku jest więcej optymizmu. Garczyński pisze: „Moje zdrowie polepsza się: w lekach ciągłych jestem, piję wody salzbruńskie, może Bóg dopomoże” (Drezno, 25 VIII 1832; s. 91). W kolejnym liście zawiadamia: „Doktor radzi jechać na południe; nie wiem co zrobię, do ciebie naprzód wpadnę" (Drezno, 16 X 1832; s. 91). Ale już 26 listopada martwi się bardzo z powodu pogorszenia się stanu zdrowia: „Wstawili mu dubeltową fontanellę [tj. urządzenie do upuszczania krwi - G. S.] na ręku, bodajby to cokolwiek pomogło" (Drezno, 26XI 1832; s. 93). Cieszy się jednocześnie w owym liście $z$ dobrego stanu zdrowia przyjaciela i nakazuje mu bardzo szanować się, bo go „Polska jednego tylko posiada, o niej pamiętać należy!” (tamże). A 7 grudnia donosi Garczyński Mickiewiczowi, że mu jego lekarz Heidenius śmiercią zagroził, gdyby „gdziekolwiek zimową wyruszył porą" (Drezno, 7 XII 1832; s. 95). To polecenie lekarza skłoniło Garczyńskiego do pozostania na zimę w Dreźnie, ponieważ ,jeszcze z rok przeciągnąć sobie życzył” (tamże), na wiosnę zaś przyszłego roku planuje spotkanie z Adamem w Szwajcarii lub we Włoszech.

${ }^{40}$ Zob. biogram Klaudyny z Działyńskich Potockiej (1801-1836): Polski Stownik Biograficzny, t. 27, Wrocław 1983, s. 743-744 (D. Wawrzykowska-Wierciochowa).

${ }^{41}$ Problemy związane z udziałem Mickiewicza w edycji dzieł poetyckich Stefana Garczyńskiego omawiają prace: S. Tarnowski, Stefana Garczyńskiego „Wactaw” i drobne poezje, „Przegląd Polski” 1872 z. 9, s. 177-223; T. Pini, Rękopis poezji Garczyńskiego w przerobieniu przez Mickiewicza, „Pamiętnik Literacki” 1898, s. 435-480; tenże, Mickieuricz jako urydawca poezji Garczyńskiego, Lwów 1898; B. Zakrzewski, Ktopoty korektorskie z „Poezjami” Stefana Garczyńskiego, „Pamiętnik Literacki” 1963 z. 2, s. 553-557; Z. Szelag,, Mickiewicz jako korektor „Sonetów wojennych” Stefanla Garczyńskiego „Pamiętnik Literacki” 1963 z. 3, s. 127-131; tenże, Uwagi o chronologii i formowaniu „Waclawa dziejów” Stefana Garczyńskiego, „Pamiętnik Literacki” 1976 z. 1, s. 149-165; Z. Stefanowska, Mickiewicz o "Wactawa dziejach" Garczyńskiego. [w:] taż, Próba zdrowego rozumu. Studia o Mickiewiczu, Warszawa 1976; Z. Stajewska, „Wacława dzieje” Stefana Garczyńskiego, Wrocław 1976. 
Mówi też o polepszeniu się jego stanu zdrowia mimo ciągłego kaszlu oraz o ponownym leczeniu metodą upuszczania krwi.

Mickiewicza niepokoił bardzo zły stan zdrowia Garczyńskiego. W liście do przebywającego w Dreźnie Odyńca pisze 8 grudnia 1832 roku: „Donieś mi w szczególach o zdrowiu Stefana; choroba jego jest nowym dla mnie ciosem, strasznie mię smuci i ile razy wspomnę o was, świat mi brzydnie: tyle wszędzie dokoła smutku" (Paryż, 8XII 1832; XV 50). 7 stycznia 1833 roku pisze zaś do brata Franciszka: „Garczyński choruje w Dreznie, co też wielkim dla mnie jest nieszczęściem, bo bardzo do niego przywiązałem się i bardzo mi tęskno bez niego" (Paryż, 7 I 1833; XV 52).

Z kolei Garczyński w liście z 8 stycznia 1833 roku donosi Mickiewiczowi, że dopiero wiosną, zgodnie z przewidywaniami lekarzy, polepszy się jego stan zdrowia, a wówczas w kwietniu uda się do Włoch. Mieszkał on wtedy u Klaudyny Potockiej, będąc pod jej troskliwą opieką. Ponieważ znów zachorował na zapalenie płuc, skłoniło go to do głębokiej refleksji, że „nie chciałby (...) jeszcze ze świata tego uciekać” (Drezno, 9 I 1833; s. 96). Następnie pyta o zdrowie Adama, nakazuje mu: „Tobie, tobie szanować się trzeba, mnie lada kto, ciebie nikt by zastąpić narodowi nie mógł" (tamże).

Mickiewicz nieustannie troszczył się o Garczyńskiego: „Jak zdrowie twoje? Napisz mnie obszerniej" - prosił w liście ze stycznia (Paryz, 12 I 1833 XV 55), a w liście do Odyńca z tegoż miesiąca wyrzucał sobie, że namawiając kiedyś Stefana do picia wód mineralnych, spowodował szybszy rozwój jego grú́licy (Paryż, 28 I 1833; XV 57).

25 lutego 1833 roku pisze Garczyński do Mickiewicza: „Moje zdrowie polepsza się z wolna. Kaszlam przecież wciąż jeszcze, tylko nie tak gwałtownie. Konna jazda wzmacnia i ożywia cokolwiek" (Drezno, 25 II 1833; s. 99). Adama natchnęła lepszym humorem wieść o tym, że Stefan jest zdrowszy, a wiedząc o tym, że przepracowuje się pisząc wiersze, błagał z rozpaczą (Paryż, 5 III 1833; XV 59): „Nie pisz teraz nic, póki całkiem nie wyzdrowiejesz; Goethe powiedział, że nie trzeba psuć sił i ekspensować an ein Bild des Lebens" [ «na obraz życia», który nie jest rzeczywisty - G. S.]

Podobnie 17 marca Garczyński narzekając na zły stan zdrowia doszedł do wniosku, żc spowodowało go napisanie wiersza Piersi moje zbolałe..., który posłał Mickiewiczowi. Pisze znów o puszczaniu krwi, które polepszyło nieco stan jego zdrowia, zmniejszając kaszel, i pokłada „W Bogu nadzieję”, „że jednak coraz lepiej będzie” (Drezno, 17 III 1833; s. 101). W tymże liście projektował też wyjazd do południowej Szwajcarii, zgodnie z zaleceniami lekarzy.

Na wieść o powodach przyspieszenia choroby przyjaciela Mickiewicz ponownie błagał go: „Zmiłuj się, już nic nie pisz i nie myśl, pókiś chory. Ucisz w sobie człowieka, a pielęgnuj zwierzątko; reperuj okręt, a potem kapitan zacznie robić obserwacje i nabijać harmaty" (Paryż, 8 IV 1833; XV 65). Zawiadamia Stefana, że sam jest zdrów.

Pogoda wiosenna znacznie pogorszyła zdrowie Garczyńskiego. Stosowanie medykamentów takich jak ośle mleko i zabiegów upuszczania krwi okazało się bezskuteczne. Pozostała jeszcze jedna metoda leczenia — zmiana klimatu, dzięki której poeta ma „w Bogu nadzieję” 
że „kaszel odstąpi” (Drezno, 17 IV 1833; s. 101-102). Chce więc koniecznie wyjechać z Drezna na południe.

Następny list Mickiewicza do Garczyńskiego z 6 maja 1833 roku musiał być odpowiedzią na jakiś zaginiony, skoro poeta pisze w nim: „List twój ostatni ucieszył mię, bo w nim nic o twoim zdrowiu nie piszesz, skąd wnoszę, że musi być lepsze" (Paryż. 6 V 1833; XV 72). Dalej autor listu wspomina o przebytej niedawno dziesięciodniowej grypie, z której szczęśliwie wyleczył się.

14 maja Garczyński informuje Mickiewicza o powiększeniu się kaszlu, a w związku z tym o planach wyjazdu do Bex blisko Vevey w Szwajcarii na tzw. kurację serwatkową i udania się do Włoch jesienią. Poeta, „niepodobny do siebie”, z „wyziębioną duszą uśpioną lekarstwami” pisze, że „przez ciągły kaszel i połykanie lekarstw ustawiczne dziwnie na ciele i duszy upadl” (Drezno, 14 V 1833; s. 103-105). Pesymistycznie powiada: „Wszakże i tak nie wiedzieć, czy kuracja moja zdrowie mi przywróci; w Bogu jednym nadzieja" (tamże; s. 104).

Mickiewicz, śląc z Paryża list po liście, dopytywał się nieustannie o zdrowie przyjaciela. Ostatni ze znanych listów do niego zaczyna słowami wielkiego niepokoju z powodu kolejnego pogorszenia się jego stanu zdrowia, o czym dowiedział się od generała Jana Umińskiego. Pisze następnie, że z powodu trudności paszportowych i finansowych trudno będzie spotkać się $\mathrm{z}$ adresatem listu w Strasburgu, a jeśli tylko otrzyma pozwolenie na wyjazd, postara się „koniecznie do tego Bex czy Gex pojechać do Szwajcarii, aby się z [nim] spotkać” (Paryż, 23 V 1833; XV 74). Tego samego dnia Mickiewicz napisał do Odyńca, martwiąc się chorobą przyjaciela: „Odgadniesz, ile mnie to boli. Stefan jest z ludzi, którzy i drugim, i nam tak potrzebni do życia" (Paryż, 23 V 1833; XV 77). Następnie poleca przekazanie Stefanowi kartki z jakąś informacją (niestety nie dochowała się ona do naszych czasów), gdyby choroba zatrzymała go w drodze, po czym deklaruje: „Jeżeli będę mógł, pobiegę do Szwajcarii do Stefana" (tamże).

Garczyński był coraz słabszy, coraz bardziej chory. Ówczesna medycyna była bezsilna wobec gruźlicy, która niszczyła organizm pacjenta. 27 maja pisze on do Mickiewicza z Frankfurtu: „dnia trzeciego przejażdżki (...) kaszel mię konwulsyjny porwał i blisko 24 godzin łamał (...) [i go] uspokoić nie mogę!" (Frankfurt, 27 V 1833; s. 105-106). W liście tym donosi Mickiewiczowi, że będzie sześć dni w Strasburgu, skąd popłynie do Bazylei, a potem do Bex na kurację serwatkową.

W ostatnim liście, wysłanym już ze Strasburga 5 czerwca 1833 roku, Garczyński opisuje dość obszernie przyjacielowi symptomy swojej choroby: „Kaszel mój do podróży nagli. Wzmógł on się do takiego stopnia, że pewne tylko potrawy i o pewnych godzinach jeść mogę, inaczej zaraz w konwulsyjny się zamienia i wymioty gwałtowne. Katar przyłączył się na nieszczęście do kaszlu i gdyby nie anielskie staranie pani Potockiej, nie wiem, jakim bym sposobem podróż tak długą odprawił" (Strasburg, 5 VI 1833; s. 106-107). Wyraża nadzieję, że w Bex wyleczy się. Jego drezdeński lekarz Heidenius dał mu listy do lekarzy szwajcarskich, a on sam jest „receptami i lekarstwami jak aptekarz podróżujący opatrzony” (tamże). 
5 lipca 1833 roku Mickiewicz wyjechał z Paryża do Bex ${ }^{42}$. Na miejsce dotarł 8 lipca w towarzystwie Klaudyny Potockicj, którą spotkał przypadkowo w czasie podróży.

9 lipca donosi Odyńcowi: "Jestem od wczora w Bex. Stefan ma się lepiej nieco od czasu, jak tu stanął; chce koniecznie udać się stąd do Włoch i mnie w drogę zaprasza. Sam też udać się w żaden sposób nie może, a ja przewiduję dla siebie wielkie trudności. Obaczymy, jak się to uda. (...) Jadąc z Lausanne na statku spotkałem przypadkiem panią Potocką, płynącą z Genewy do Stefana. Pojmiesz, jaka to była dla mnie siurpriza!” (Bex, 9 VII 1833; XV 83). Garczyński pragnął wyjechać do Włoch, wierząc, że południowy klimat poprawi jego stan zdrowia. Mickiewicz, starając się myśleć realniej, pisze z nutą rezygnacji do brata Franciszka: "chciałbym go odprowadzić, ale trudności wielkie i nie widzę sposobu, jak je załatwić” (Bex, 9 VII 1833; XV 86). Sam był wtedy zdrowy i gdyby nie choroba przyjaciela, byłby — donosił bratu — nawet zadowolony z podróży do Szwajcarii. Poeta myślał z niepokojem, co się stanie, jeśli wyjedzic Klaudyna Potocka i on zostanie przy chorym sam (tamże, s. 86). Owa Samarytanka pełniąc posługę przy chorym, ,jak anioł opiekuńczy utrzymuje duszę w Stefanie. Ta kobieta godzi z rodzajem ludzkim i może natchnąc znowu wiarę w cnotę i w dobroć na ziemi, (...) znajduje zawsze siły na służenie innym” — pisał o Potockiej Mickiewicz do Ignacego Domeyki „w czasie snu Stefana” (Bex, 9 VII 1833; XV 87-88). Skarży się w tym liście, że tutejsi lekarze wiedzieli niewiele na temat gruźlicy oraz o leczeniu jej podawaniem owczej serwatki (żętycy). Smutkiem napawa go widok „twarzy pięknej Stefana, takiej bladej i smutnej"; sam, pacjent nie tylko nie mógł robić wycieczek w góry, ale nawet trudno mu było „wychylać sic̨ za próg” (tamże, s. 87). Udręką był więc sam widok Stefana, który nikł w oczach. Mickiewicz obserwował symptomy jego konania i bardzo krótkie remisje, nie rokujące nadziei na przyszłość.

Kiedy prawie miesięczna kuracja serwatkowa nie przyniosła rezultatów, Mickiewicz 21 lipca 1833 przywiózł chorego przyjaciela do Genewy i zatrzymał się z nim w Hôtel de l'Elçu, gdzie zamieszkała również pani Potocka ${ }^{43}$.

Po tygodniu pobytu Mickiewicz pisze do Domeyki: „Jesteśmy od tygodnia w Genewie. Dalej nie możemy ruszyć i dla trudności pasportowych i dla słabego zdrowia Stefana. Mieliśmy dni okropne, ale teraz lepiej. (...) Przez cały ten czas nic robić nie mogę i nie wiem, kiedy wrócę do zatrudnień. Z domu bardzo rzadko wychylam się" (Genewa, 26 lub 27 VII 1833; XV 89). Jego cały czas jest przeznaczony dla chorego przyjaciela. Pierwszy raz w życiu obserwował beznadziejną walkę człowieka ze śmiercią, przez co czuł się zmęczony psychicznie. W kolcjnym liście do Domeyki pisał na początku sierpnia z Genewy: „Stefan tak był słaby, że przez kilka godzin co dzień patrzyliśmy na wszystkie symptomata konania. Możesz wystawić sobie moje położenic. (...) Ja przyznam siç, nie mam żadnej nadziei! Może tylko do jesieni lekarstwa życie mu utrzymają. Nie mogłem nigdzie wyjść i często po kilka dni ze stancji nie wychylam się. Znaleźliśmy tu Klaudią Potocką, zresztą nikogo widzieć nie

42 Datę tę podaje Zdzisław Szeląg, op. cit., s. 146.

4.3 Zob. tamże, s. 146-147. 
mam czasu. (...) Łatwo zgadniesz, iż przy odgłosie kaszlu i patrząc na ciągłe cierpienia Stefana nie podobna myśleć o pisaniu, a nawet czytaniu" (Genewa, 2 VIII 1833; XV 90-91). A w parę dni później Mickiewicz pisząc do tegoż oburzał się: „Garczyński (...) Istny to męczennik! Po co go wywlekli z Drezna, nie pojmuję. Kiedy stąd wyjedziemy, nie wiem, bo to zależy i od zdrowia Stefana i od jego chęci, które naturalnie zmienne, równie jak stan zdrowia", a sam czuł się „zupełnie z nóg zwalony” (Genewa, 12 VIII 1833; XV 92). Chwilami, kiedy zdrowie uległo minimalnej poprawie, Garczyński zaczynał myśleć o wyjeździe ze Szwajcarii. 12 sierpnia donosił o tym Mickiewicz bratu Franciszkowi: „(...) chciałbym go do południowej Francji odprowadzić, bo sam podróżować nie może" (Genewa, 12 VIII 1833; XV 93). Chory miał jeszcze złudzenie, że wyjeżdżając do południowej Francji i Włoch powróci do zdrowia. Mickiewicz, poczuwszy się lepiej i pozbywszy bólu zębów oraz nerwowego kaszlu, podjął decyzję podróży na południe i wziął na siebie trud przewiezienia Stefana. Nie miał jednak złudzeń, bo był przekonany, że „doktor i wszyscy wysyłają go co najrychlej, bo w takich chorobach każdy rad dalej pacjenta wysyłać. Wyjeżdżamy tedy jutro do Lyonu, stamtąd mamy płynąć Rodanem do Awinionu. Będziemy jechać niezmiernie powoli, jak dojedziemy, Bogu wiedzieć!" - pisał do Domeyki (Genewa, 28 VIII 1833; XV 95).

$\mathrm{Z}$ listów poety wyłania się gehenna tej podróży. Aby ratować chorego przyjaciela, Mickiewicz wydaje ostatnie pieniądze. 7 września 1833 roku pisze do Domeyki: „Przywiozłem Stefana z Genewy do Awinionu. (...) Możesz wystawić sobie biedy podróży z chorym, którego na ręku z pojazdu do mieszkania dźwigać trzeba w kraju, gdzie oberżyści, spojrzawszy nam w oczy i widząc w nich niewiele życia, przyjmować nas nie chcą! (...) Źle bardzo z nami. (...) Mamy zamiar jechać do Marsylii, stamtąd do Włoch, zamiar popierany przez wszystkich doktorów, chociaż dodają w ucho, że chory w Marsylii albo na morzu życie zakończy. (...) Jestem tak strudzony, tak bezsenny, że dłużej pisać nie mogę" (Avignon, 7 IX 1833; XV 95-96).

Chociaż Mickiewicz nie miał już żadnych złudzeń, aby jednak pocieszyć i uspokoić przyjaciela, „bo jakże byłoby dowodzić mu, że tej podróży przedsięwziąć nie jest w stanie” (do Ignacego Domeyki, Marsylia, 18 IX 1833; XV 96), wyruszył do Marsylii, żeby starać się o paszport. Opiekę nad Stefanem zdał przybyłemu właśnie do Awinionu Tadeuszowi Pągowskiemu, dawnemu przyjacielowi umierającego poety. Aby pojechać do Awinionu, Pagowski „porzucił pracę, sprzedał zegarek, a także część rzeczy osobistych i dotarł do Garczyńskiego około 12 września. Z pomocą Mickiewicza, a dla pożegnania chorego pośpieszył z Paryża także Józef Bohdan Zaleski (nie zdążył), a wreszcie Klaudyna Potocka z mężem (Bernardem), którzy zjechali do Awinionu 17 września, a więc w czasie, gdy Mickiewicz znajdował się w Marsylii”" ${ }^{44}$. W Marsylii otrzymał poeta od Pągowskiego list - alarmujące wezwanie do natychmiastowego powrotu do Awinionu, gdyż stan zdrowia Garczyńskiego znacznie pogorszył się i lada dzień można się było obawiać najgorszego. Na wieść o tym poeta powziął

${ }^{44}$ Z. Szelagg, op. cit., s. 156. 
decyzję o powrocie 18 września, zamartwiając się, że jedzie patrzeć „na (...) gaśnienie miłej osoby" (do Ignacego Domeyki, Marsylia, 18 IX 1833; XV 97).

Strawiony gruźlicą Garczyński już dogorywał. Jego śmierć nastąiła w piątek 20 września 1833 roku o godzinie 6 rano $^{45}$.

W liście do Odyńca (Avignon, 22 IX 1833; XV 98) tak relacjonował poeta to smutne wydarzenie:

Nasz Stefan już przed dwoma dniami przestał cierpieć. Wróciłem właśnie z Marsylii, gdzie jeździłem niby po paszporta do Włoch i znalazłem naszego przyjaciela przez kilka dni mojej niebytności bardzo zmienionego. W nocy o godzinie szóstej przestał oddychać; tak lekko usnął, że nie można nazwać skonaniem tej krótkiej chwili przejścia z biedy na świat lepszy. Cierpiał Stefan wiele w Bex i w Genewie, potem ustały bole fizyczne, dręczyła go tylko niecierpliwość, chęć prędkiego przenoszenia się z miejsca na miejsce, a razem uczucie wzmagającej się słabości. Śmierć swoję często przepowiadał, ale też równo często pełen był nadziei, a w ostatnich dniach więcej niż kiedykolwiek. Wiozłem go z wielką trudnością od Genewy do Avignon. Tu, na wielkie moje szczęście, dopędził nas dawny znajomy Stefana, Pagowski, zacny człowiek. Ten mię wspomógł w moich kłopotach i zastał przy chorym, kiedy wyjeżdżałem do Marsylii. Wyperswadowaliśmy Stefanowi, aby czekal w Awinionie na paszport, ale rzeczywiście już go niepodobna było z miejsca ruszyć.

Przybyła też kilku dniami przed jego śmiercią p. Potocka i osłodziła mu ostatnie chwile na ziemi. Tej nocy, kiedy żyć przestał, byłem przy nim do późna; potem, znużony bezsennością i drogą, poszedłem spać. Pągowski czuwał przy lóżku. Przerażony zbyt cichym snem chorego, zbliżył się i znalazł go bez życia.

W liście do Ignacego Domeyki napisał zaś: „Nasz Stefan już nas porzucił, pozawczora o godzinie szóstej z rana usnął z lekka na wieki. (...) Znalazłem go po kilku dniach niewidzenia zmienionym bardzo, ale był przytomny i rad bardzo memu przybyciu; mówił już z wielką trudnością, po południu już rzadko się do nas odzywał i to tylko prosząc o lekarstwa, o światło lub pomoc" (Avignon, 22 IX 1833; XV 99). Nad ranem wezwany przez Garczyńskiego Pagowski poprawił mu pościel, a w pół godziny potem „nie słysząc oddechu chorego, przybiegł i znalazł go bez życia" (tamże). Poeta donosił następnie, że zmarły ostatnio mało cierpiał, skarżąc się jedynie na osłabienie, uniemożliwiające mu dalszą podróż.

Mickiewicz, który swoje cierpienia zwykł zamykać w sobie, w tymże samym liście do Domeyki, bolejąc po stracie przyjaciela, pisał te słowa: „Jestem podobny teraz do Francuza wracającego z 1812 roku, zdemoralizowany, słaby, obdartus zupełny, bez butów prawie. O niczym myśleć dotąd nie mogę" (tamże, s. 100). Autor listu stał się ruiną materialną

${ }^{45}$ Zob. tamże, s. 157. 
i moralną, miał mocno nadwątlone zdrowie, gdyż po raz pierwszy tak blisko zetknął się ze śmiercią.

28 września pisze do brata Franciszka o śmierci Garczyńskiego: "Wiesz, jak ścisła przyjaźń nas łączyła, i domyślisz się, ile mię strata jego dotknęła. (...) Wystawić sobie możesz moje położenie z umierającym przyjacielem, którego byłem długo jedynym stróżem, nim mię w Avenionie dawni jego znajomi nie wspomogli i nie wyręczyli" (Avignon, 28 IX 1833; XV 100-101).

21 września 1833 roku Stefan Garczyński został pochowany na awiniońskim cmentarzu. Budowy grobowca podjął się Mickiewicz, który też ułożył łacińskie epitafıum:

$$
\text { D. O. } M \text {. }
$$

Stephanus Garczyński

Miles

In bello contra Moscoviae Tyrannum

Equitum Posnaniensium

Centurionis vices gessit

Vates

Polonorum arma virosque cecinit

Patria a Tyranno oppressa

$$
\text { Exul }
$$

Obiit Avenione

Annos natus XXVII ${ }^{46}$

Poniżej na białej marmurowej tablicy wykuto napis polski ${ }^{47}$ ( $n b$. z błędną pierwszą datą):

$$
\begin{gathered}
\text { Stefan Garczyński } \\
\text { Jazdy poznańskiej porucznik } \\
\text { Krzyża wojskowego kawaler } \\
\text { Ur. w Kosmowie } 1806 \text { r[ok]u }
\end{gathered}
$$

Um. w Awenionic d. 20 września 1833

Koszta nagrobku pokryła Klaudyna Potocka ${ }^{48}$.

${ }^{46}$ „Stefan Garczyński. Żołnierz. W wojnie przeciwko moskiewskiemu ciemiężcy sprawował funkcje porucznika jazdy poznańskiej. Poeta. Opiewal czyny wojenne Polaków. Po zgnębieniu ojczyzny przez tyrana wygnaniec. Zmarł w Avignon w 27 roku życia" (tłumaczenie za: Z. Sudolski, Mickiewicz. Opowieść biograficzna, Warszawa 1995, s. 391). Tekst napisu nagrobnego Garczyńskiego zob. A. Mickiewicz, Dziela, Wydanie Jubileuszowe, t. 13: Pisma różne, Warszawa 1955, s. 218; tlumaczenie: tamże, s. 270. Autograf znajduje się w Bibliotece Kórnickiej PAN.

${ }^{47}$ Tekst za fotografią w: M. Danilewiczowa, op. cit., po s. 66.

${ }^{48}$ O nagrobku Stefana Garczyńskiego piszą: W. Mickiewicz, Żywot Adama Mickiewicza, op. cit., t. 2, s. 278; tenże, Grób druha Adamowego, „Tygodnik Ilustrowany” $1910 \mathrm{nr}$ 48, s. 970; L. Méyet, Mickiewicz nad grobem Garczyńskiego w Awinionie, „Przewodnik Naukowy i Literacki” 1896, s. 473-478; P. Mączewski, Garczyński 
Gdy Mickiewicz powrócił po przeszło trzech miesiącach nieobecności do Paryża 18 października, nazajutrz pisal do Hieronima Kajsiewicza: „Przybyłem tu wczoraj z południowej Francji. Przyjaciel mój, Stefan Garczyński, skończył życie w Avignon. Wiele mnic z nim ubyło; tak to coraz to przyjacicle moi przeprawiają się na drugą stronę i coraz świat pod starość pustoszeje” (Paryż, 19-21 X 1833; XV 102). Na te „słowa niepojęte w świetle zwykłego rachunku dat biograficznych" ${ }^{49}$. zwracają uwagę Alina Witkowska i Maria Danilewiczowa $^{50}$. Pocta miał wtedy niespełna trzydzieści pięć lat, a po śmierci przyjaciela był wyczerpany psychicznie i fizycznie. Pogrążony w depresji, myślał o własnej starości. „Ciężka to jest walka życie!” - napisze prawie dwa miesiące później w nastroju klęski i osamotnienia do Hieronima Kajsiewicza i Leonarda Rettla (Paryż, 16 XII 1833; XV 112).

Zły stan zdrowia Mickiewicza objawiał się w trudnych do określenia bólach „chodzących po zębach, głowie i piersiach", o czym pisał w połowie listopada 1833 roku do Odyńca (Paryż, 13 XI 1833; XV 103). Zatrzasnął za sobą drzwi mieszkania i zabrał się do pracy nad piątą i szóstą pieśnią Pana Tadeusza. W tymże liście poeta nie szczędzi sobie samemu wyrzutów: „nieraz (...) Stefanowi w czasie jego choroby nie mogłem (...) wstrzymać się, aby co przykrego nie powiedzieć, albo milczeniem zagniewanym karcił (...) dziwactwa słabości, którym trzeba było przebaczać. My mężczyźni nigdy nie osiągniemy tej doskonałości moralnej w pobłażaniu i przebaczaniu; przekonałem się o tym patrząc na Potocką" (tamże, s. 104). Możemy zauważyć w tych słowach wrażliwość i ogromne wyczucie autora listu.

Ślad cierpień Mickiewicza spowodowanych śmiercią Garczyńskiego widoczny jest pod koniec księgi dziesiątej Pana Tadeusza. Wspomnienie o jego zgonie zaznacza się w obrazic umicrającego Jacka Soplicy:

Biłem się za kraj; gdzie? jak? zmilczę; nie dla chwały

Zicmskiej biegłem tylekroć na miecze, na strzały.

Milej sobie wspominam, nie dzieła waleczne

I głośne, ale czyny ciche, użyteczne,

I cierpienia, których nikt... 51

i Mickiewicz. (W setną rocznicę śmierci Stefana Garczyiskiego), „Kurier Warszawski” 1933 nr 261, s. 4-5; W. Borowy, Co się stato z nagrobkiem Garczyńskiego?, „Wiadomości Literackie” $1933 \mathrm{nr}$ 54, s. 2; S. Pigoń, Inskrypcje nagrobne Adama Mickiewicza, „Ruch Literacki” 1937 nr 9-10, s. 177-180; J. Sztaudynger, O poecie, któremu Mickiewicz wystawil pomnik w Avinionie, „Czas” 1938, nr 177, s. 9; M. Danilewiczowa, op. cit., s. 68-69; S. Skwarczyńska, Aspekt wergiliański jednej z uypowiedzi Mickiewicza o Stefanie Garczyńskim i jego znaczenie dla wiedzy o wzajemnym stosunku obu poetów, [w:] taż, Pomiędzy historiq a teoriq literatury, Warszawa 1975, s. 56-67. Zwłaszcza wers „Polonorum arma virosque cecinit” Skwarczyńska określa jako świadoma parafrazę pierwszego wersu Eneidy Wergilego: „Arma virumque cano...”, co nasuwa skojarzenie podobieństwa losów Eneasza i Garczyńskiego, walecznych żołnierzy, a potem wygnańców, a także jest porównaniem polskiego poety do wieszcza rzymskiego.

${ }_{49}^{4}$ A. Witkowska, Mickiewicz, Słowo i czyn, Warszawa 1986, s. 188.

${ }^{50}$ Op. cit., s. 62.

5! A. Mickiewicz, Dzieła, Wydanie Jubileuszowe, t. IV: Pan Tadeusz, Warszawa 1955, s. 298 (ks. X: Emigracja. Jacek, w. 836-840). 
Tak spowiadał się na łożu śmierci Jacek Soplica, a w tej spowiedzi dostrzec można oddźwięk tego, co i może nieraz pomyślał sobie sam Mickiewicz. I tak też, jak sądzę, Garczyński istnieje w Jacku Soplicy. Śmierć bliskiej Mickiewiczowi osoby znalazła w nim swoje odbicie.

\section{6.}

Mickiewicz poświęcił Garczyńskiemu trzy wykłady w swoim kursie literatur słowiańskich, wygłoszone 17, 21 i 28 czerwca 1842 roku w Collège de France. Autor prelekcji nobilitował go do rangi tego, który „powziął zamiar utworzenia filozofii polskiej”, kiedy „przeniknąwszy (...) podstawową myśl filozofii Heglowskiej poznał, że była ona nieprzyjazna Polsce ${ }^{, 52}$. Uznał też swego przyjaciela za najbardziej polskiego poetę, geniusza, którego oczekuje naród, dopatrując się w jego poemacie filozoficznym Wactawa dzieje „najobszerniejszego (...) utworu, jaki istnieje w językach słowiańskich" ${ }^{53}$. Autorowi prelekcji utwór wydal się mesjanicznym, a sam Garczyński jawił się jako największy polski poeta, dążący ku prawdzie młody artysta, błądzący pomiędzy rozumem a uczuciem, wreszcie dążący do zgody marzeń z rozumem. Mogło to wynikać $z$ faktu, że poemat jest niedokończony i że romantyzm preferował formy otwarte ${ }^{54}$. Sam Wacław zdaniem Mickiewicza „to istota na kształt Fausta, na kształt Manfreda" ${ }^{55}$, pożerana wewnętrznym niepokojem, a napędzana zarozumiałością i pychą. Ale Zofia Stefanowska zauważa, że „wyniesienie Wacława dziejów na szczyty poezji polskiej (...) to świadoma strategia wykładowcy, który w syntezie literatury nie mógł pominąć tej roli, jaką odegrała Dziadów cz. III - a nie chciał mówić o niej wprost i po imieniu. Wactawa dzieje potraktował więc do pewnego stopnia jako pseudonim własnego dzieła i w rozbiór poematu Garczyńskiego włączył uwagi o III cz. Dziadów. Można więc w wykładach o Garczyńskim wyczytać autorski komentarz do dramatu drezdeńskiego, (...) tym bardziej (...) cenny, że poeta skąpy był w sądach na temat własnej twórczości"56.

Myślę, że Mickiewicz tak wysoko oceniał ten nieukończony poemat Garczyńskiego oraz inne jego wiersze i uczynił z Wacława dziejów arcydzieło ${ }^{57}$, bo ich autor stał się częścią życia

52 Tamże, t. X: Literatura stowiańska. Kurs drugi, przeł. [z franc.] L. Płoszewski, Warszawa 1955, s. 381 (wykład XXX, 17 VI 1842); por. A. Mickiewicz, Prelekcje paryskie, opr. M. Piwińska, t. 2, Kraków 1997, s. 148.

${ }_{53}$ Tamze, s. 382; Prelekcje paryskie, op. cit., s. 149.

${ }^{54} \mathrm{O}$ „sztuce pisania nie wykończonych za życia papierów” pisze S. Kierkegaard, Albo-albo, przeł. [z duń.] J. Iwaszkiewicz, t. 1, Warszawa 1976, s. 172. O romantycznej „,formie otwartej” zob. M. Janion, Czas formy otwartej. Tematy i media romantyczne, Warszawa 1984, zwlaszcza s. 289.

${ }_{55}$ Literatura slowiańska, op. cit., s. 383; Prelekcje paryskie, op. cit., t. 2, s. 149.

${ }^{56}$ Z. Stefanowska, Mickiewicz o "Wactawa dziejach” Garczyńskiego [w:] taż, Próba zdrowego rozumu. Studia o Mickiewiczu, Warszawa 1976, s. 122-123. O wysokiej ocenie poematu Garczyńskiego przez Mickiewicza zob. Mirosław Strzyżewski, O Mickiewiczowskiej nobilitacji poematu Stefana Garczyńskiego „Waclawa dzieje”. Zapomniany krytycznoliteracki aspekt wyktadów paryskich Adama Mickiewicza, „Pamiętnik Literacki” 1998 z. 1, s. 27-38.

57 "Utwory literackie są arcydziełami w czyimś odczuciu, w jakimś czasie i przestrzeni, choć jednocześnie zbyt szczupły zasięg funkcjonowania obniża ich rangę, a nawet pozbawia tytułu do specjalnego wyróżnienia. Utwór jest (...) arcydziełem o tyle i tak długo, o ile i jak długo (...) w danych warunkach i przez danych odbiorców [jest] oceniane jako wartościowe"(R. Handke, Kategoria horyzontu oczekiwań odbiorcy a wartościowanie dziel literackich [w zbiorze:] Problemy odbioru i odbiorcy. Studia pod red. T. Bujnickiego, J. Sławińskiego, Wrocław 
Mickiewicza, bohaterem jego „ukrytego dramatu (...), którego ślady można raczej wyczuć niż wyczytać w wykładach" żyć tak, jak się pisze"

1977, s. 102). Por. tenże, Oddzialywanie literatury w perspektynie odbiorcy, „Teksty” $1974 \mathrm{nr} 6$, s. 90-106.

${ }_{58}$ M. Piwińska, Dzieje kultury polskiej w prelekcjach paryskich, [wstęp do:] A. Mickiewicz, Prelekcje par'skie, op. cit., t. 1, s. 69; „(...) Mickiewicz cytuje Garczyńskiego coraz częściej w trzecim i czwartym semestrze. Nieduze to cytaty, po kilka wierszy. Nie po to są, żeby je interpretować. Mickiewicz punktuje nimi swe myśli, służą mu jako poetyckie potwierdzenia i podsumowania" (tamże).

${ }_{59}$ A. Mickiewicz, Dzieła, Wydanie Jubileuszowe, t. XI: Literatura stowiańska. Kurs trzeci, przeł. [z franc.] L. Płoszewski, Warszawa 1955, s. 32 (wykład III, 20 XII 1842); Prelekcje paryskie, op. cit., t. 2, s. 188. 